\title{
AN ANALYSIS OF SALVATION FROM THE PERSPECTIVE OF CHRISTIANITY AND ISLAM
}

\author{
${ }^{1}$ Abdrassilov Turganbay, ${ }^{2}$ Nurmatov Zhakhangir, ${ }^{3}$ Kaldibay Kaynar \\ Iturganbay33@mail.ru, ${ }^{2} z h a k h a n g i r . n u r m a t o v @ a y u . e d u . k z,{ }^{3} k a l d i b a y k a y n a r @ l i s t . r u$ \\ ${ }^{1,2,3}$ Khoja Ahmet Yassawi International Kazakh-Turkish University
}

(Turkestan, Kazakhstan)

\author{
${ }^{1}$ Абдрасилов Турганбай Курманбаевич, ${ }^{2}$ Нурматов Жахангир Ешбайевич, \\ ${ }^{3}$ Қайнар Қалдыбай

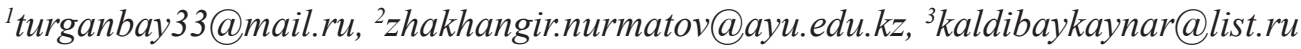 \\ ${ }_{1,2,3}$ Международный казахско-турецкий университет \\ имени Ходжи Ахмеда Ясави (Туркестан, Казахстан)
}

\begin{abstract}
This article intends to investigate this issue objectively and honestly without bias from the comparative viewpoint between Islam and Christianity. The methodology of the article is to have a comparative analysis of the concept of salvation in both Islam and Christianity by presenting the similarities and differences. This article utilises passages from the Qur'an and the Gospel as primary sources, which will be complemented with journal articles as a secondary source. The first section looks at the terminology of 'salvation' within Islam and Christianity from the viewpoints of sin, repentance and forgiveness, as salvation in both Christianity and Islam means saving from the consequences of sin, and in both religions this involves repentance by humans and forgiveness by God. The second part of this article will examine how Muslims and Christians view Jesus in relation to salvation. This is tied to salvation because the death and resurrection of Jesus is how Christians believe salvation has been accomplished. The final section of this article analyses the God doctrine of Christianity and the God concept of Islam from the comparative perspective with regards to the topic of salvation. This comparative analysis will be important in highlighting the similarities between the two Abrahamic faiths, and that such commonalities can be used as a basis for respect and peaceful co-existence between Christians and Muslims.
\end{abstract}

Key words: Salvation, Islam, Christianity, the Koran, the Bible, God, Jesus

\section{Introduction}

Although the topic of salvation has drawn special attention from Muslim and Christian scholars alike and has a significant amount of research dedicated to it, there is still a need for re-examination as due to globalisation and modernisation, the world has become a small village which has brought people with different convictions together. Salvation has been a significant topic among those of inter faith dialogue and among people with different faiths. Holding an exclusive view - that is, claiming that only certain groups of people deserve salvation - would not lead to integrity and social cohesion. Despite Islam and Christianity both deriving their origin from the prophet 
Abraham [1, p. 25.], both religions hold different interpretations of salvation [2, p. 183.]. These essential differences are reflected in the theology, teachings and practice of both religions. Salvation is an integral part of religion, without which religion would not have any meaning [3, p. 199.]. The rationale for considering exploration of this topic relates to the good intention of establishing a friendly, mutually beneficial relationship between Muslims and Christians.

\section{Methodology}

The article compares the concept of salvation in Islam and Christianity. The methodology of the article is a comparative analysis of the concept of salvation in both Islam and Christianity, showing similarities and differences.

The solution of the research tasks is based on the extensive research of scientists in this field, the general methodology of scientific knowledge.

Also, the method of historical and cultural, comparative, hermeneutic, ontological, anthropological, axiological, conceptual analysis, which is widely used in the humanities, was used in the study of the topic. In addition, the methods of comparative-historical and historical-philosophical analysis were widely used in the article.

\section{The Terminology of Salvation}

The Islamic and Christian concepts of salvation are complex. According to Kenneth, salvation can be interpreted differently depending on the conviction of the believer. In Islam, the Arabic term in the Qur'an najaa means salvation from Earthly troubles and sins [4, p. 46.]. Siddiqi explains that this term, in the noun form, appears only once in the Qur'an, but in the verbal form emerges approximately sixty-four times suggesting that this term is used differently in different contexts, meaning to save from disasters or other worldly difficulties and, at the same time, saving true believers from the punishment of hellfire. This shows that the Qur'an highlights two parts of salvation: salvation from worldly difficulties, and salvation from hell. People have two parts: the material part and the spiritual part. Salvation in this context means to save all humans from destruction and from punishment. In Islam, the root of all problems stems from people's sins, and salvation from them after having faith in Allah, through repentance [5, p. 21.]. As the Quran 2:22 states, "Indeed, Allah loves those who are constantly repentant and loves those who purify themselves". Being in a state of tawba (repentance) is, for a Muslim, to strengthen one's faith and to allow humans to resist doubt and despair, which can so often obscure faith. This shows that by being consciously in the state of tawba, humans can process remorse and achieve "closure' for the acts they have committed that were less than worthy of Allah's love. It enables faith to be strengthened because it enables the believer to fully face themselves and their weaknesses, making them stronger. The Prophet Muhammed stated, "Every son of Adam commits sin and the best for those who commit sin are those who repent" (Sunan Ibn Majah). It seems that the Prophet Muhammed understood human weakness and understood that humans could be in a state of sin and repentance whilst, at the same time, being viewed as the best of humanity, because being in a state of tawba, for Muslims, is to enable a higher 
standing with Allah, because it enables humans to attain a more righteous outcome. Only by facing our own flaws, and reflecting upon them through the state of tawba, do humans fully attain an understanding of themselves and therefore a full understanding of the beauty of Allah [5, p. 23.]. Tawba is, therefore, an internal process which allows individuals to attain closeness to Allah, through a multi-stage process outlined in the teachings of the Prophet. The more self-aware an individual is, within Islam, the more they can obtain from the process of tawba. Faith and a high level of self-awareness protects Muslims from sin, despair and disillusionment with the material world, with the tawba state being a constant act of reverence and worship that, in itself, offers the salvation of a life well lived [6]. It is evident that salvation in Islam is achieved via repentance; in other words, human beings are accountable for their deeds, meaning whether to be saved or damned depends on their decision. Conversely, in Christianity, the Bible understands the term 'salvation' as Jesus being the ultimate saviour of humankind [7, p. 120.]. This idea of an external being offering salvation to humankind is an integral part of Christianity. Jesus himself in Gospel provides the following statement regarding salvation: "I am the way, and the truth, and the life. No one comes to the Father except through me". (John 14:6). This shows that in Christianity, salvation is only achievable through Jesus Christ. According to Christianity, the execution of Jesus on the cross was the last and universal sacrifice that was carried out for the forgiveness of the sins of humanity. Even though the Christian religion is not the exclusive owner of the ideology of redemption, it has rendered to it a dominative and definite position. Acts 13:23 says that Jesus is the promised saviour for Israel. Isaiah 12:2 states "surely God is my salvation; I will trust and not be afraid". These passages from the Bible illustrate that salvation is not achieved; rather, it is granted through faith and trust. Most Christian theologians agree that salvation is attainable only by the mighty work of Jesus Christ, who is God's Son, being crucified on the cross [7, p. 125.]. This clearly indicates that human beings with their deeds cannot achieve salvation, as it is a blessing from God as a gift for having faith and trust. One can easily see that here; salvation is an external process which can be attained through faith which suggests that people are naturally sinful. For example, Paul claims that sin is destructive and the consequences are hazardous. Therefore, sin must be cleansed via repentance and asking for forgiveness. Paul further states that sin cannot be forgiven by repentance, but by the blood of Jesus. This repentance act is realised with the recognition of Jesus being sacrificed for the redemption of all human beings, suggesting that repentance in Christianity is vital. According to Eerdmans dictionary of the Bible [8, p. 324.], repentance is defined as complete transformation of mind which consequently results in changing of the human manners. Both in Hebrew term "naham" and in Greek "metanoeo" which denote change of mind, suggest that the repentance comes through Jesus who preached his followers to repent with his name. This shows that the repentance is made by admitting that those who repent will get the divine assistance implying that through the Holy Spirit, Christians repent and feel remorse by discarding the sins of the past and starting a new life. As Apostle Paul notes "If anyone is in Christ, he is a new creation: the old has gone; the new has come" $[9$, p. 32.]. Thus, in Christianity repentance exists, but in a slightly different form from Islam. It is through Jesus and not via hard work as in Islam. For example, Luke 17:7-10 implies that their salvation does not depend upon their work, for no person can do more than is required of him. Thus no one can do excess work 
which might serve as an atonement for his evil deeds. Paul asserts that Christ can be relied upon to save, based on the following qualities. Firstly, Jesus Christ is sinless, as admitted even by Muslims, and he is the word and spirit of God. Secondly, Jesus Christ, according to Christians, is perfect God and perfect man. This perfection exempts him from sin. These qualities, according to Paul, suggest that Jesus is the man who can offer salvation, as supported by the following verse: "Even as the Son of Man came not to be served but to serve, and to give his life as a ransom for many" (Matthew 20:28). Therefore, due to the love and mercy towards human beings, Jesus Christ was sent, and in order to meet the requirement of justice he was sacrificed with his blood. "In this is love, not that we loved God but that he loved us and sent his Son to be the expiation for our sins" (John 4:10). When looked at from the comparative perspective on sin and repentance, the sin conception in terms of the cause of all evils is similar, whereas the repentance perception is slightly different. In Islam, the servant repents by having pity on himself, while in Christianity repentance is made by meditating on the atonement and sacrifice of Jesus and his being tortured for all human beings - in other words, recalling or pitying on the suffering of Jesus for his redemption for all humans is what makes Christians repent. The main difference between Islam and Christianity, regarding salvation, is that in Islam, salvation is achieved internally, meaning constant repentance and the responsibility of human beings which make Muslim people save themselves [10, p. 98.] (Stanton and Weitbrecht, 1919), whereas in Christianity salvation is attained externally. In other words, Jesus as a saviour takes away all sins on the condition of faith in him.

\section{Concept of Jesus From the Perspective of Islam and Christianity}

This section will explore the concept of Jesus from the perspective of Islam and Christianity. Islam and Christianity (and Judaism) follow the same Abrahamic tradition which suggests that Abraham was the Prophet of God, with Muslims viewing Islam as being the culmination of the three Abrahamic faiths and viewing both Christians and Jews as worthy of protection as Islam views them both as also being "Peoples of the Book" [11, p. 110.]. According to Robinson, the Qur'an and the New Testament are congruent in many details such as the blessedness of Mary, the virgin birth of Jesus, his title as Messiah, his miracles such as healing the blind and lepers, raising the dead, and his roles as servant and prophet [12, p. 51.]. Despite these similarities between what is written about Jesus, and his actions and example, in the Bible and the Quran, there are major differences between the Islam story of Jesus and the Christian story of Jesus. The main difference is that Muslims do not believe that Jesus was crucified. Roberts notes that whilst Islam, via the Qur'an, does not acknowledge that Jesus was crucified $[13$, p. 316.], the historical event of Jesus' crucifixion is recorded in the Qur'an 4: 157158, which states:

"That they said (in boast) "We killed Christ Jesus the son of Mary, the Messenger of Allah" - but they killed him, not crucified him, but it was so made to appear them, and those who differ therein are full of doubts, with no (certain) knowledge, but only conjecture to follow, for of a surety they killed him not-nay, Allah raised him up unto Himself and Allah is exalted in Power, Wise". 
This passage of the Qur'an acknowledges that Jesus was killed but calls people who believe in the crucifixion "full of doubts", suggesting that they engage in conjecture as to how Jesus was killed. Besides, four Gospels note the death of Jesus (Matt 27:45-50, Mark 15:33-39, Luke 23:44-49, John 19:28-30. They unanimously affirm the death of Jesus Christ by indicating to the fact that Jesus relinquished his spirit or breathed his last spirit out, implying that he died with his will and wish. Mark suggests that the curtain was split, demonstrating that this refers to the event in which God declared that crucified Christ granted the access to God for the believers and the prayer of Jesus "My God, my God, why have you forsaken me?" (Matt 27:46) shows that he was experiencing suffering and pain, which is again indicative of his genuine will to die by suffering for the atonement of the sins. Peterson quotes what Jesus says, "I, when I am raised up from the earth, will attract all people to myself". According to John, Peterson argues, the "lifting up" of Jesus is his physical crucifixion on the cross and metaphoric exaltation. The ambiguity here means not that Muslims know how Jesus was killed, just that they know he was killed, leaving Muslims equally "full of doubt" as the Christians that are identified by the Qur'an as being "full of doubt" [13, p. 317.]. As with all historical texts, their meaning is open to interpretation; as Roberts discusses, the crucifixion is a fundamental aspect of Christianity, as it is a symbol of death as redemption. The fact that there is disagreement between Muslim scholars as to what the Qur'an 4:157-158 passage means, and therefore between Muslims and Christians as to what these differences in beliefs mean for our coexistence on Earth, reflects the differences in Muslim and Christian conceptions of ideas such as salvation [14, p. 205.]. For Muslims, Christ may or may not have died that day, but for Christians, Christ did die that day: this informs the way Christians practice their faith and for most Muslims, this debate largely does not affect the way in which they practice their own faith on a day-to-day basis. For Christians, the cross is a symbol of ultimate love; for Muslims, the process of tawba can be likened to this level of faith in the power of regeneration (of thoughts) to lead to repentance and to regeneration. However, Schoot, with regards to Jesus's crucifixion, based on the argument of Thomas Aquinas, claims that both Jews and Muslims theologically and philosophically will be outraged by the statement that the Word of God suffered and died, and they often deride it [15, p. 143.]. Aquinas appears to criticise Muslims for their lack of wisdom in discussing the suffering and death of Christ. He further states that the suffering and demise of Jesus shows an example of virtue for his adherents. His weakness and humbleness proves the reliability of his preaching, and the innocent suffering and death of Jesus for the redemption of the world suits the justice of God and human nature, according to his free willpower $[15$, p. 145.]. It should be noted that Christ took a human nature to reinstate manhood after the descent. For this reason, Christ would have suffered in order to redeem for the sin of human beings with his human nature. Therefore, the Son of God with his human nature demonstrated that human beings ought to consider temporal things as nothing, and showing love to worldly things prevents man from spiritual things. Schoot, based on the claim of Aquinas, asserts that Christ thus decided to live a poor life, disregarding wealth and dignity. He was thirsty, hungry, and even experienced hardships, eventually undertaking the most atrocious type of death - that is, on the cross. By this, 
the Son of God showed an example to pursue for the virtue that is confirmed by Peter: "Christ suffered for you, and left an example for you to follow in his steps" (I Peter 2. 21). Further, based on Aquinas, Schoot maintains that the order of justice necessitates the sin to be punished by a penalty that 'corresponds' to the size of the crime $[15, \mathrm{p}$. 145.]. Christ takes the punishment upon himself by redeeming us by blotting out our guilt in the way that divine justice demanded. He further asserts that sin is a crime against God, and as God is infinite, therefore the crime against him requires infinite satisfaction. Finite man is not able to deliver it. Then, in his love, God invents a special 'means': he sends his only begotten Son instead of man. Thus the Son of God satisfies divine justice [15, p. 147.]. This shows that God, in his chosen form of redemption, revealed his special love to the world. He could have forgiven sin for nothing. But by doing so, God would make it clear that man is not of great value to him. God desired to make humanity a partaker of his salvation and forgiveness by showing grace in Christ, the true man, and then in the life of every individual human being. All people, by the power of the Holy spirit, are called to participate in life, in Christ, and in their own salvation through faith, repentance, and obedience. Despite the fact that Christianity and Islam interpret the crucifixion of Jesus differently, both the Muslim faith and the Christian faith view their own perception of 'salvation' as having certain conditions that need to be met before this process can occur: a sin needs to have been committed; there needs to be some degree of repentance on the part of the sinner; there needs to be faith in the higher power that salvation will be attained/conferred; and there needs to be concurrent good works committed by the sinner, in order to show the higher power the intention to renew, replenish and restart the efforts to be sinless [10, p. 121.].

\section{Doctrine of God From the Perspective of Islam and Christianity}

This section explores the doctrine of God from the Christian perspective compared to the Islamic perspective. There are distinct differences between Islam and Christianity regarding the form that the divine being assumes. With regards to the Trinitarian doctrine, Smith asserts that God is only one who is in three persons - Father, Son, and Holy Spirit $[16$, p. 78.$]$. Smith further explains the Trinity as covert and unfathomable truth that is apprehended through personal knowledge. This shows that the God doctrine in Christianity is complex and God can be known only through the Son of God who encompasses all the treasures and knowledge within him. Smith further states that the triune God of Christianity is truthfully and entirely personal in comparison to God of Islam, suggesting that God is not like in Islam who is eternally alone that does not accept companionship, communication and love [16, p. 85.]. The argument of Smith is supported by Zwemer (1946) who compares the God concept of Islam with the God doctrine of Christianity in relation to salvation. Zwemer [17, p. 65.], in his essay based on the summation of William G. Palgrave, describes Allah as the single power, motion, vitality and action. The rest is clear inactivity and pure instrumentality from the highest echelon to the lowest atom. Hence, unmeasurably and everlastingly glorious and unlike all creatures in terms of motionlessness, Allah is one in omnipotence. He himself is barren in his unreachable loftiness, he does not love or enjoy anything except his own self-determination with no son, companion and adviser 
$[17$, p. 68.]. His argument shows that God in Islam does not accept fatherhood which is crucially important in the Christian faith, and is defined as one who cannot be interacted with in a friendly manner, but rather authoritarian who must be shown obedience and who lacks the redeeming love attributes. This kind of God, Zwemer asserts, cannot provide salvation as $\mathrm{He}$ is deprived of attributes such as genuine love and fatherly care. In addition to this, he argues that God of Islam, although described as compassionate and forgiving, lacks the absolute holiness and righteousness meaning although sin and grace is mentioned in the Qur'an, guilt and love is not mentioned. Zwemer further states that there is no synchronisation in the attributes of Allah [17, p. 70.]. They are dispersed as ninety-nine beads on the Moslem rosary as they are held together via cord, whereas the concept of Trinity exposes the accord of God's essence in his loftiness and prominence and Christ being the person of Trinity demonstrates the true unification between the Creator and the creature. In Islam, Allah can forgive the sinner by abolishing his law and pardoning culpability with no penalty, implying that the Muslim faith misses the Cross of Christ as it is the essence of Gospel. The God of Islam is barren, as Allah is self-sufficient of himself and is beyond comparison to any creature and he is completely remote from his creatures. His argument illustrates that that Islam does not accept the companionship between God and man, as God is too glorious for that and man is so inferior in the theocentric atmosphere of Islam. One can easily see that Islam is the religion of regular man whereas Christianity is the religion of spiritual pursuer after God. These evidences show that the God who is outside of Jesus and the Holy Spirit is a vague idea and lacks reality. Zwemer suggests that even Muslim Sufi such as al-Ghazali encountered the issue of Islamic theism; that is, the transcendence and immanence of God without incarnation. He attempts to show in his essay that there is a need for a mediator between God and the creatures and that mediator is absent in Islam, whereas Jesus Christ, the second person of the Trinity, is the one to perform this liaison. As Karl Barth (cited in Marvinam and Vahidi) argues, our endeavour to attain redemption or salvation is impossible as human beings do not have the capacity to reunite with God using personal attempts, implying the need for external assistance that is Jesus Christ [18, p. 105.]. In other words, perfection or salvation is only attainable through Jesus Christ who is sinless and the second person of the Trinity, indicating that He is the God who revives the dead heart through the Holy Spirit. This is supported by Nasr who states that the Sufi Rumi claim that the breath of Jesus has power to revive the heart of people, as he raised the dead, suggesting that the dead heart can only be enlivened through faith in Jesus who, with his spiritual power, attracts the Holy Spirit to raise the dead heart and resuscitate it to the new world [19, p. 98.]. While orthodox Islam denies the Trinity God concept of Christianity, when analysed from the perspective of Sufism of Islam, the God concept of Christianity in terms of gaining salvation is similar. For example, Jones states that Smith discovered similarities in the comprehension of God between his personal faith and Sufi [20, p. 106.]. In Sufism, the master that is the mediator between God and truth seeker plays a crucial role in obtaining salvation or perfection for the truth seeker, which is similar to the role of Jesus Christ who enlivens the dead hearts of followers by attracting the Holy Spirit. According to prominent scholar and theologian of Islam Ghazzali [21, p. 145.], Sufism is the internal part of Islam that deals with the inner world of human beings, meaning truth or true knowledge is obtained by cleaning the heart. He further states that the heart can be cleaned first by faith 
and then by following the instructions of a reliable spiritual instructor who is the mediator between God and truth seeker. His argument suggests that obtaining true knowledge or wisdom necessitates the internal eyes of humans to be opened; in other words, it is realised firstly via faith and secondly by trusting the master and obeying the instructions of the spiritual teacher - without whom true knowledge or salvation is impossible. Despite the striking differences in the God concept of orthodox Islam and Christianity, there is a similarity between the Christian Trinity concept and the Sufism doctrine of God in terms of mediator between God and creature. Overall, there are many similarities between Islam and Christianity regarding the doctrine of their God, but these similarities are often forgotten due to the many differences between the understanding of the doctrine of God in the two faiths. It is shameful that two religions that are so similar, and which both actively preach the golden rule, should still disagree, practically, on so many doctrinal aspects, to such an extent that religious persecution still leads to the loss of human life. Human constructions of the Divine will always lead to conflict; for this reason, it is important for believers to exercise their faith by working on, and implementing, the doctrines of their faith and, in this way, ensuring that conflict does not override the central tenets of their faith, which are essentially to act in the image of their chosen divine being - be this God or Allah [14, p. 58.].

\section{Conclusion}

To sum up, this study revealed that whilst Christianity and Islam can both trace their roots back to the Prophet Abraham, and both claim to worship the same God, both religions have different interpretations of the life of Jesus, and the idea of salvation. These essential differences created a difference in the theology, teachings, and practice of both religions in regards to understandings of sin, the concepts of human weakness and human fallibility, and the need for repentance and forgiveness. Islam and Christianity have more similarities than differences, with the main differences between the two religions being some aspects of the life and doctrine of Jesus, as understood through readings and analyses of the sacred texts of both religions. It is important to remember that religion, through its theology, is a subjective matter, open to interpretation according to one's personal dogma and how this dogma affects one's lived experiences. Concepts that invite reflection, such as tawba, enable tolerance to be generated within, and therefore amongst, individuals, even if the individuals differ in their beliefs and their understanding of their sacred texts. This essay would like to conclude with a parable from Khalil, who brings as an example the Indian parable of the blind men and the elephant, where the parts of the elephant were described based on the feelings of each person [22, p. 35.]. He further claims that this type of pluralism was argued by John Hick, who claimed that numerous world religions made different attempts to explain the same truth. By bringing this example he suggests that all paths lead to paradise and disputing over the topic which is beyond our comprehension should not create conflict; rather, it should assume the form of friendly discourse. Therefore, I would like to state that judging whether somebody is saved or not belongs to God; the main essential point is to have faith and then hold on to the ethical values so that there is happiness and cohesion in society. The disagreement over how/when/whether Jesus was killed does not need to be a source of conflict. Part of 
the central dogma of the Muslim and Christian faiths is the golden rule that is the basis of all religious faiths developed by humankind [23, p. 28.], with Muslims expressing this golden rule thus: "None of you truly believes until he wishes for his brothers what he wishes for himself" and Christians expressing the golden rule, via Matthew 7:12, thus: "Do unto others as you would have them do unto you".

\section{List of references}

1 Peters, F.E. The children of Abraham: Judaism, Christianity and Islam. - Princeton: Princeton University Press, 2004. - $264 \mathrm{p}$.

2 Hoover J. Islamic universalism: Ibn Qayyim al-Jawziyya's Salaff deliberations on the duration of Hell-Fire // Muslim World, 2009. Volume 99. - PP. 181-201.

3 Paul S.M. A Muslim's journey to salvation // International Journal of Frontier Missions. - 13(4). - 1996. - PP. 197-204.

4 Siddiqi M.H. Salvation in Islamic Perspective // Islamic Studies. - 32(1). - 1993. - PP. 41-48.

5 Al-Ghazzali M. Al-Ghazzali on repentance. - London: Kazi Publications, 2003. - 31 p.

6 Tahir R. Repentance, redemption and salvation: An Islamic framework. [Electronic resource]. URL https://yaqeeninstitute.org/roohi-tahir/repentance-redemption-salvation-an-islamic-framework/\#.XepMGRSHVcw (accessed $1^{\text {st }}$ December 2019).

7 Peterson R.A. Salvation accomplished by the Son. The work of Christ. - Illinois, USA: Crossway Wheaton, Illinois, 2011. $-624 \mathrm{p}$.

8 Freedman D.N. Eerdmans Dictionary of the Bible. - Wm.B. Eerdmans publishing, 2000. $-1480 \mathrm{p}$.

9 Etzioni A., Carney D.E. Repentance: A comparative perspective. - Rowman and Littlefield, 1997. $-196 \mathrm{p}$.

10 Stanton H.U.,Weitbrecht M. The Teaching of the Qur'an. - London: Central Board of Missions and Society for Promoting Christian Knowledge, 1919. - 146 p.

11 Armstrong K. Muhammad: A prophet for our time. - London: Modern Library Chronicles, 2013. $-256 \mathrm{p}$.

12 Robinson N. Christ in Islam and Christianity. - USA: State University of New York Press, 1991. $-262 \mathrm{p}$.

13 Roberts N. A Muslim reflects on Christ crucified: Stumbling block or blessing? // Islam and Christian-Muslim Relations. - 24. - 2013. - PP. 313-331.

14 Armstrong K. Islam: A short history. - London: Modern Library Chronicles, 2016. - $230 \mathrm{p}$.

15 Schoot H.J.M. Christ crucified contested: Thomas Aquinas answering objections from Jews and Muslims. // The three rings: Textual studies in the historical trialogue of Judaism, Christianity and Islam. - Tilburg University, 2005. - PP. 141-162.

16 Smith R.A. Trinity and reality. An introduction to the Christian faith. - Moscow, Idaho: Canon Press, 2004. -242 p.

17 Zwemer S.M. The Allah of Islam and the god of Jesus Christ // Theology Today. - 3(1). - 1946. - PP. 64-77.

18 Marvinam M., Vahidi S. A comparative study of salvation from the viewpoints of Motahari and Rahner // Religious Inquiries. - 8(15). - 2019. - PP.103-122.

19 Nasr S.H. The Islamic view of Christianity // KATHA - Journal of Dialogue of Civilizations. - 4. - 2008. - PP. 94-106.

20 Jones R.J., Cantwell Smith W., Cragg K. On Islam as a way of salvation // International Bulletin of Missionary Research. - 1992. - PP. 105-108.

21 Ghazali A.H.M., Ghazali I.A.H. The marvels of the heart: Ihya ulum al-din // The revival of the religious sciences. Translated by Walter James Skellie. - USA: Fons Vitae, 2010. - 242 p. 
22 Khalil M.H. Between heaven and hell: Islam, salvation and the fate of others. - Oxford University Press, 2013. - 368 p.

23 Cooper I. The golden rule. - London: Springer, 2016. - 32 p.

24 Donaldson D. Studies in Muslim ethics. - Cambridge: Cambridge University Press, 1963. $-304 \mathrm{p}$.

\section{Абдрасилов Т.К., Нұрматов Ж.Е., Қалдыбай К. Құтқарылу түсінігінің христиан мен ислам тұрғысынан талдануы}

Aңдатnа. Бұл мақалада ислам мен христиандағы құтқарылу түсінігі салыстырмалы түрде қарастырылады. Мақаланың әдіснамасы - ұқсастықтар мен айырмашылықтарды көрсете отырып, исламда да, христиан дінінде де құтқарылу тұжырымдамасына салыстырмалы талдау жасау. Бұл мақалада Құран мен Інжілдің үзінділері негізгі дереккөздер ретінде пайдаланылады, ал ғылыми мақалалар екінші дереккөздер ретінде толықтырылады. Бірінші бөлімде күнә, тәубе және кешірім тұрғысынан ислам мен христиан діндеріндегі құтқарылу терминологиясы қарастырылады. Өйткені христиан дінінде де, исламда да күнәнің салдарынан құтқарылу деген сөз және екі дінде де бұған адамның тәубасы және Құдайдың кешірімі сияқты сенім орын алған. Мақаланың екінші бөлімінде мұсылмандар мен христиандардың Исаға байланысы құтқарылуға қатысты көзқарастар талданды. Өйткені, Исаның өлімі мен қайта тірілуі арқылы мәсіхшілер тарапынан құтқарылу орындалды деп санайды. Мақаланың соңғы бөлімінде Құдайдың христиандық ілімі мен исламдағы Кұдай тұжырымдамасын құтқару тақырыбына байланыстыра отырып, салыстырмалы талдау жасалынады. Бұл салыстырмалы талдау екі аврамдық сенімнің ұқсастығын анықтау тұрғысынан маңызды болады, әрі осындай ұқсастықтар, христиандар мен мұсылмандар арасындағы сыйластық пен бейбіт өмір сүру үшін негіз ретінде пайдалануға ұсынылады.

Tүйін сөздер: Құтқарылу, ислам, христиандық, Құран, Інжіл, Құдай, Алла, Иса

\section{Абдрасилов Т.К., Нурматов Ж.Е., Калдыбай К. Анализ спасения с точки зрения христианства и ислама}

Аннотация. Эта статья направлена на объективное исследование концепции спасения с точки зрения ислама и христианства. Методология статьи состоит в том, чтобы провести сравнительный анализ концепции спасения как в исламе, так и в христианстве, показывая сходства и различия. В качестве основных источников использованы Коран и Евангелие, которые дополнены научными статьями в качестве вторичных источников. В первом разделе статьи рассмотрена терминология спасения в исламе и христианстве с точки зрения греха, покаяния и прощения, поскольку спасение как в христианстве, так и в исламе означает спасение от последствий греха, а в обеих религиях это включает человеческое покаяние и прощение Богом. Во второй части статьи мы исследуем, как мусульмане и христиане относятся к Иисусу в контексте идеи спасения. Это связано с тем, что смерть и воскресение Иисуса - это вера христиан в то, что спасение свершилось. В заключительном разделе статьи мы анализируем доктрину Бога в христианстве и концепцию Бога в исламе относительно темы спасения. Этот сравнительный анализ важен для выявления сходства между двумя авраамическими верованиями и того, что такие общие черты могут использоваться в качестве основы для уважительного и мирного сосуществования христиан и мусульман.

Ключевые слова: Спасение, ислам, христианство, Коран, Библия, Бог, Иисус, Аллах. 